\title{
Manga Translation and Censorship Issues in Malaysia
}

\author{
*YEAN FUN CHOW \\ HASURIA CHE OMAR \\ WAN ROSE ELIZA ABDUL RAHMAN \\ School of Humanities, Universiti Sains Malaysia, 11800 USM, Pulau Pinang, Malaysia \\ *Corresponding author: yeanfun.chow@usm.my
}

Published online: 31 May 2021

To cite this article: Yean Fun Chow, Hasuria Che Omar and Wan Rose Eliza Abdul Rahman. 2021. Manga translation and censorship issues in Malaysia. KEMANUSIAAN the Asian Journal of Humanities 28(1): 1-21. https://doi.org/10.21315/kajh2021.28.1.1

To link to this article: https://doi.org/10.21315/kajh2021.28.1.1

\begin{abstract}
In manga translation, when original image and written representations are regarded as inappropriate content to the target readers' socio-cultural context, censorship is imposed. Nevertheless, research on censorship in manga translation in Malaysia has not been given due attention. Previous studies show that self-censorship influences translation, but it is not examined within the scope of manga translation. As such, the objective of this study is to examine the censorship practices in manga translation in Malaysia. This study adopts a qualitative content analysis approach to analyse six Malay translations and their respective source texts based on the publishing guideline of the Printing Presses and Publications Act 1984 [Act 301] and translation procedures proposed by Klaus Kaindl. The analysis shows that the censorship practice in manga translation is a combination of institutional and self-censorship. In institutional censorship, the translation procedures of detraction, addition, substitution, deletion and couplets are used, while in self-censorship, the process is involves substitution, deletion and addition. The current study recommends the adoption of institutional censorship procedures as guidelines in handling sensitive representations and a review of the self-censorship procedures to ensure faithful translations.
\end{abstract}

Keywords and phrases: censorship, sensitive representations, manga, translation procedures, self-censorship

\section{Introduction}

Manga is a Japanese word referring to comics in general and this term is widely used to refer to Japanese comics (O'Hagan 2007). Japanese major publishers established affiliates and subsidiaries to distribute translated manga and mangarelated products to overseas markets. VIZ Media in the United States and Shogakukan Asia in Singapore (Japan Book Publishers Association 2017) is a 
case in point. On 5th November 2015, Kadokawa Corporation bought $80 \%$ of Art Square Group's shares in Malaysia to expand the comic and manga industry (Kadokawa Corporation 2015). These facts show that manga exhibits a wide readership globally as well as in Malaysia. Yet, manga translation, which plays an important role in the spread of manga, is often neglected in Translation Studies (Jüngst 2004; O'Hagan 2007; Rampant 2010; Huang and Archer 2014; Borodo 2015; Takeyama and Armour 2015). Manga is less studied in the field of translation because Western comics are often used as samples (Jüngst 2004, 83) but manga is not accepted as media content and researchers demonstrate insufficient knowledge of Japanese language (O’Hagan 2007).

Censorship plays an important role to ensure a translated manga is appropriate to the target context. In Malaysia, all publications are required to gain approval from the Ministry of Home Affairs prior to mass production and distribution. A publishing guideline titled "Garis Panduan Penerbitan di bawah Akta Mesin Cetak dan Penerbitan 1984 [Akta 301]" (The Publishing Guideline under the Printing Presses and Publications Act 1984 [Act 301]) is introduced as the guideline for all publishers in the preparation of their content. A publication will be considered as "prohibited" or "unwanted" if it causes any danger to public order, morality and security, stagger public's mind, contrary to the law or harmful to the public and national interest (Bahagian Kawalan Penerbitan dan Teks Al-Quran 2017). However, noting that the guidelines are statements depicting prohibited contents, crucial and specific ways in which to handle the "dos and don'ts" of published materials are not mentioned.

In the study on humour translation, Hanim Hafiza (2014) discovered that some modifications had been carried out to censor humour conveyed through taboo messages in manga. However, to date, no studies have been performed to determine the specific types of translation procedures adopted by manga translators and publishers to perform censorship in order to produce a translated version, which is in line with the publishing guideline, as well as whether or not self-censorship is imposed on manga translation in Malaysia. In relation to that, this article aims to answer three questions pertaining to censorship in the translation of manga: (1) How do the translators and publishers perform institutional censorship in line with publishing guideline?, (2) How do the translators and publishers perform self-censorship, which is not stated in the guideline? and (3) What translation procedures can be adopted by manga translators and publishers as guidelines to handle sensitive representations in manga of different genres? 


\section{Literature Review}

\section{Censorship issues}

Censorship is an obligatory procedure adopted to modify or block cross-cultural interactions, and it is governed by a set of values or criteria established by a country, religious institutions or social conventions. Censorship can be divided into institutional censorship and individual censorship. Institutional censorship is a preventive measure that functions effectively as the government enforces it to the publishing industry. In individual censorship, which is also known as self-censorship, translators play the role of self-censors and perform censorship prompted by their assumptions on public interest (Billiani 2009, 28-30).

Studies on censorship in manga translations have been conducted by researchers such as Kaindl (1999), Rota (2008/2014) and Zanettin (2008/2014a; 2008/2014b; 2014; 2018). Zanettin (2018) explained that censorship in manga translation in the European countries is prompted by political, cultural and economic factors; moral acceptability and vulnerability of target readers. Rota (2008/2014) shares the same opinion that modification in translated manga can be done due to cultural and political factors. Cultural censorship is imposed when a cultural element is considered as "strange" in the target cultural context. The element may be omitted or substituted with something familiar to the target cultural context. Political censorship refers to the deletion of political elements and references. However, in some cases, the author's or the translator's profile may cause a text to be censored or banned, as some of the names are seen as sensitive content creators (Billiani 2009, $30)$. Censorship can also be prompted by religious factors. Zitawi (2008/2014) explains that censorship regulations in the Gulf area include monitoring content that is not in line with Islamic teachings. As such, romantic and sexual references, magic, God and horoscopes are omitted, while the human body and images of pigs are blurred to obscure it from sight in publications in the Gulf, so as to avoid sensitivity among the Arab readers who are mainly of the Muslim faith (Zitawi 2008/2014). Contents that are censored also include offensive words (Billiani 2009), violence, sexuality, brutality, political propaganda, symbol of sensuality, page size, publication format and Jewish names (Zanettin 2014; 2018).

\section{Translation procedures}

Among the procedures that are frequently employed in the translation of manga are the following: (1) adapting size to fit publication format, (2) retouching and deleting panels, (3) eliminating sensitivities and unbecoming verbal and visual elements (Zanettin 2018), (4) paraphrase and (5) non-translation, where 
original texts remain in the translation (Billiani 2009). Zanettin (2014) adopts a localisation perspective to study visual adaptations in comic translation. Three panels of manga are also used as data for discussion. By combining six translation procedures proposed by Kaindl (1999), namely repetitio, deletio, detractio, adiectio, transmutatio and substitutio, and also Celotti's six translation procedures to translate linguistic paratext, namely translated, translated with a footnote in the gutter, culturally adapted, left untranslated, deleted, and a mix of (some of) the mentioned procedures in his analysis, Zanettin (2014) concluded that all procedures were applied in comic localisation, while repetitio and left untranslated are default options.

In Malaysia, manga became popular under the "Look East Policy". In the early 1980s, cultural contents such as video games, anime, manga, drama, music and so on were imported to Malaysia (Ye 2010, 87). Manga series such as Doraemon, Dragon Ball, Detective Conan and Crayon Shin-chan are translated into Malay, English and Mandarin so that all readers from different races in Malaysia can read them. Although Hanim Hafiza's (2014) research on the translation of humour in manga explains the modifications made to elements of humour that are considered as taboo, no previous studies have been conducted to examine the censorship in manga translations in Malaysia based on the publishing guideline issued by the Ministry of Home Affairs. In Malaysia, manga is popular among teenagers and children. These young audiences are the future of the country (Roslina et al. 2018, 298, 301), and their favourite contents should be handled with caution. Therefore, there is a need for this study to be carried out in order to examine censorship in the field of manga translation in Malaysia.

\section{Self-censorship}

Zanettin $(2014,32)$ explains that in some cases, the censorship carried out is not in compliance with regulations set by the authorities or legislative bodies but it is still imposed to ensure that the translation is in compliance with cultural and taboo conventions. This kind of self-censorship is also imposed under pressure from the media, public and private organisations. Publishers, authors or translators often perform self-censorship as an attempt to avoid legal, economic or physical loses that may result from violation of written or unwritten law (Zanettin 2018, 7, 11). This indicates that different publishers are likely to apply different types of selfcensorship, which is not listed in the publishing guideline. 
According to Billiani $(2009,28)$, censorship and translation affect the visibility and the invisibility as well as the accessibility and inaccessibility of cultural capital that can be enjoyed or produced in specific texts. This means that the censorship performed should be in accordance with the publishing guideline. If extreme self-censorship is imposed to a translation, it will affect the message gained from the translation and be less accessible than it should have been. The significant influence of self-censorship on messages led to studies of self-censorship. For example, Barrale (2018) examines the political stance of the Fascist regime on translation by focusing specifically on contemporary German popular fiction and examines the tendency of publishers and translators in imposing self-censorship to avoid direct censorship interventions. To prevent interference from the regime, the findings of the study show that publishers often use self-censorship.

In Malaysia, a study on self-censorship conducted by Badrul Redzuan (2015) examined the prospects of self-censorship in the film industry. However, selfcensorship in manga translation has been relatively neglected, although selfcensorship is an important factor to be considered in order to ensure that the resulting translation conveys the original author's message and at the same time complies with publishing guideline.

Based on the literature review that has been presented and considering Billiani's $(2009,28)$ opinion, a need exists to fill in the research gaps that were stated. Therefore, this study aims to examine censorship in manga translation into Malay in Malaysia. More specifically, the study exhibits three objectives, namely: (1) to identify translation procedures used by translators and manga publishers in accordance with publishing guideline, (2) to examine self-censorship in manga translation in Malaysia and (3) to suggest the translation procedures which can be used as a guideline to provide translations that are in line with the socio-cultural context in Malaysia.

\section{Theoretical Framework}

\section{Publishing Guideline under the Printing Presses and Publications Act 1984 [Act 301]}

This study utilises the Publishing Guideline under the Printing Presses and Publications Act 1984 [Act 301] issued by the Ministry of Home Affairs and the translation procedures proposed by Kaindl $(1999,275-284)$ to identify the following: (1) translation procedures used by manga translators and publishers for institutional censorship, (2) elements that involve self-censorship and (3) translation procedures used for self-censorship. 
According to the Publishing Guideline under the Printing Presses and Publications Act 1984 [Act 301], prohibited images are images of naked men or women, the partially naked body with some parts covered with hands, leaves, blackened or blurred (mosaic) and men or women in suggestive poses, for instance, a woman lying down with her breasts in full view. Images of women wearing skimpy outfit and showing the shape of the body or sensitive parts, wearing a bikini at nonswimming sites, sitting with legs wide open and images of men or women wearing G-strings are also prohibited images. Images showing men, women or couples kissing, embracing or actions of sexual intercourse, and images of models, portraits and carvings that display a naked body and sexual organs are also not allowed in any publication. In addition, aerial photographs of places and protected areas under the Protected Areas and Protected Places Act 1959 are not permitted to be used, unless with the permission from the Department of Survey and Mapping Malaysia (JUPEM). Next, illustrations of the faces of the prophets and messengers, Khulafa' ar-Rasyidin, and their wives, angels and matters of sam 'iyyat and ghaibiyyat are also not allowed in publications. Moreover, pictures of real horrific events such as accidents, wars or bombings should not be used. Game materials (such as jigsaw puzzles and cards) with pornographic images or containing Quranic verses that can contaminate the sanctity of the Quran are not permitted too (Bahagian Kawalan Penerbitan dan Teks Al-Quran 2017, 6-7).

In terms of written content, the ones that touch upon the religious sensitivities and prejudices specific to a culture and a race, contrary to the national policy, and which threatens national security and public order, are prohibited. The use of obscene, abusive and vulgar language, including jokes are not allowed. Next, stories on cohabitation, adultery, homosexuality, heterosexuals, transgender, incest, drug abuse, gangsterism, black metal culture and subcultures such as punk, skinhead and so on are not permitted. Publications on religion other than Islam is prohibited from using special Islamic terms such as Allah, Baitullah (the House of Allah), solat (the prayer) and Kaabah (the Kaaba).

\section{Kaindl's (1999) translation procedures}

In order to identify the procedures that have been adopted to censor unwanted representations, this study adopts the translation procedures proposed by Kaindl (1999, 275-284). The procedures are repetition, deletion, detraction, addition, transmutation and substitution. Repetition (repetitio) refers to "source language, typography, or picture elements are taken over in their identical form" while size enlargement or reduction of pictorial elements are dependent on the publisher's decision. Deletion (deletio) refers to "the removal of text or pictures" while 
detraction (detractio) refers to "parts of linguistic/pictorial/typographic elements that are omitted in the translation". On the pictorial level, detraction is often used by retouching the pictures due to censorship regulations. Next, is addition (adiectio) that refers to "operations in which linguistic/pictorial material, which was not present in the original is added in the translation in order to replace or supplement the source material". Transmutation (transmutatio) refers to "a change in the order of source language or source pictorial elements", and lastly, substitution (substitutio), which includes "translation procedures in which the original linguistic/typographic/pictorial material is replaced by more or less equivalent material". Kaindl $(1999,284)$ also mentioned that "different translation strategies can be applied to individual elements within the same panel". Kaindl's procedures were adopted in this study as they can cater not only to linguistic but also to typographical and pictorial elements. Nonetheless, this study attempts to further define the proposed procedures under the lens of censorship.

\section{Methodology and Data}

According to Saldanha and O'Brien $(2014,22)$, qualitative approaches are usually associated with the interpretivist position. Interpretation is associated with the ontological position of constructivism, where priority is given to subjective understanding and interpretation of social phenomena. Through a qualitative approach, researchers attempt to explore the social world from the point of view of the actors and reflect on their own subjective interpretations (Saldanha and O'Brien 2014, 11-12). This study aims to examine how translators and publishers modify images and written messages that are considered sensitive to produce translations that fit the socio-cultural context of Malaysia, so manga translation is seen as a social phenomenon. Accordingly, to conduct this study, we used a descriptive qualitative approach.

The data for this study comprised a corpus of Japanese manga source texts and the respective target texts in Malay. The selection of target texts is carried out prior to the selection of source texts. This is because not all Japanese manga has been translated into Malay. By selecting the target texts first, the identification of the source texts becomes more appropriate.

Before April 2017, Malaysia exhibited three publishing companies publishing Malay translations of manga, namely Comics House Sdn. Bhd., Penerbit Tora Aman and Art Square Creation Sdn. Bhd. Due to the rise of online comic platforms crushing the sales of printed manga, Comic House Sdn. Bhd. ended its business in late 2016, while Penerbit Tora Aman ceased operation in April 2017. In November 
2015, the Art Square Creation Sdn. Bhd. merged with Kadokawa Corporation from Japan and changed its name to Kadokawa Gempak Starz Sdn. Bhd. The name stays until now.

To reveal the censorship practices of the three publishers, the translations selected to represent the publication of Comics House Sdn. Bhd. are Budak Getah 80 (2016a) and Budak Getah 81 (2016b) published by the company before its business ended in late 2016. The translations that represent the publication of Penerbit Tora Aman are Detektif Conan 81 (2016) and Detektif Conan 83 (2017), which were published before its business ended in April 2017. The translations representing the publication of Art Square Creation Sdn. Bhd. is Raikan Cinta (2016) while the translation representing the publication of Kadokawa Gempak Starz Sdn. Bhd. after its merger with Kadokawa Corporation is NAMAMU...01 (2016a). The respective source texts are One Piece 80 (2015), One Piece 81 (2016c) (published by Shueisha Inc.), 名探偵コナン Meitantei Conan 81 (2013), 名探偵コナン Meitantei Conan 83 (2014) (published by Shogakukan Inc.), 式の前日 Shiki No Zenjitsu (2012) (published by Shogakukan Inc.) and 君の名は Kimi No Na Wa 01 (2016b) (published by Kadokawa Corporation). Hence, the corpus of this study demonstrates purposive sampling.

According to Hsieh and Shannon $(2005,1281)$, "The goal of a directed approach to qualitative content analysis is to validate or extend conceptually a theoretical framework or theory. Existing theory or research can help focus the research question". The ultimate objective of this study is to propose a typology of translation procedures that can be used as guidelines in manga translations in Malaysia. Thus, this study adopts Kaindl's (1999) translation procedures and the directed content analysis to analyse the corpus based on the Publishing Guideline under the Printing Presses and Publications Act 1984 [Act 301] in Malaysia.

\section{Analysis and Discussion}

Table 1 represents types of censored images and written representations identified from the corpus. Throughout the corpus, three types of censored image representations are present, namely (1) sensitive body parts, (2) acts of kissing and (3) pictures of cigarettes and cigars. In addition, four types of written representations are censored in the translations, namely (1) abusive, vulgar and obscene language, (2) names of alcoholic beverages, (3) words related to religion and (4) cigarettes. 
Table 1. Types of censored image and written representations

\begin{tabular}{ll}
\hline $\begin{array}{l}\text { Censored image representations } \\
\text { as stated in guideline }\end{array}$ & $\begin{array}{l}\text { Censored written representations } \\
\text { as stated in guideline }\end{array}$ \\
\hline $\begin{array}{l}\text { Sensitive body parts } \\
\text { Kissing }\end{array}$ & Abusive, vulgar and obscene language \\
\hline $\begin{array}{l}\text { Censored image not stated } \\
\text { in guideline }\end{array}$ & $\begin{array}{l}\text { Censored written representations } \\
\text { not stated in guideline }\end{array}$ \\
\hline Cigarettes and cigars & $\begin{array}{l}\text { Names of alcoholic beverages } \\
\text { Words related to religion }\end{array}$ \\
& Cigarettes \\
\hline
\end{tabular}

\section{Translation procedures used in institutional censorship}

Table 2 represents the translation procedures used in handling the images and written messages that are considered as inappropriate contents based on the Publishing Guideline under the Printing Presses and Publications Act 1984 [Act 301].

Table 2. Translation procedures used in censoring inappropriate images and written representations as stated in guideline: Number of occurrences

\begin{tabular}{llc}
\hline Image representations & Translation procedures & Number of occurrences \\
\hline Sensitive body parts & Detraction and addition & 42 \\
& Detraction & 8 \\
& Addition & 6 \\
& Repetition & 9 \\
Kissing & Detraction & 1 \\
\hline \multirow{2}{*}{ Written representations } & Total & 66 \\
\hline Abusive, vulgar and & Translation procedures & Number of occurrences \\
obscene language & Substitution & 44 \\
& Deletion & 19 \\
& Repetition & 1 \\
\hline
\end{tabular}




\section{Sensitive body parts}

The detailed explanations in the guideline show that removing sensitive images of body parts is institutional censorship. The category "sensitive body parts" score the highest number of occurrences. Next, findings show that three translation procedures were adopted to deal with these prohibited images, namely "detraction and addition", "detraction" and "addition". Findings also show that the couplet procedure consisting of the "detraction and addition" procedures is the most frequently used translation procedure by all publishing houses understudied, in dealing with pictorial elements that depict sensitive body parts. For instance, illustrations that portray cleavage or contour of breasts in the source text were erased, and extra clothes were added in the target text by adding a curved line on the chest and another curved line below the under arms. In addition, images depicting female characters taking off their clothes and underwear like bras and G-strings, which can be clearly seen, were censored with the bras deleted (detraction) and new lines added to portray singlets instead of bras.

To deal with sensitive body image depictions, detraction is the second frequently used procedure by all publishers. It was observed that detraction is most frequently performed by erasing body contour lines. One image in the manga 君の名は 01 (2016b, 14) showing the female lead exists, with Mitsuha wearing only her undergarments and staring at her own body in front of a mirror with the sunlight shining into her room. The image was erased to create a glitter effect and this has successfully made the undergarments invisible due to the sunlight. This method has created a target text image that looked natural although modifications on it were carried out.

Addition is used by all publishers to reduce sensitivity. It is used by Comics House Sdn. Bhd. to blackened sensitive body parts via creating extra clothes. For example, a panel in the source text One Piece $81(2016 \mathrm{c}, 31)$ showed a female character wearing a special costume made up of two metal discs and a G-string. The addition procedure is employed by blackening more body parts in the target text and the additional black colour becomes part of the extra clothes which covers the contours of the character's breasts and firm abs. For the G-string, in order to reduce readers' sensitivity, the female's hip is blackened to portray safety pants. Penerbit Tora Aman also uses addition, but it is practised by applying pixelate to cover sensitive images in manga. For instance, a panel in 名探偵コナン 83 (2014, 94) exists, showing a naked victim placed in a luggage with the contours of her breasts and hips clearly seen. Pixelate is used to cover these sensitive depictions in the target text. 
Reasons why body parts are regarded as sensitive representations in Malaysia's socio-cultural context, but not in Japan, are found closely related to the social history of manga. Manga critic, Fusanosuke Natsume (1997, 185-190; 270272) explained that the works of Osamu Tezuka, who is known as the "God of Manga", exhibited a large impact on manga works after the World War II. Tezuka included image depictions of half-naked women in children's manga as he wanted to break sexual taboos at that time. Since then, manga became a medium that allows sexual taboo contents. Natsume highlighted that different countries and societies exhibit different levels of tolerance towards violence and sex. Thus, the manga environment in Japan exhibits a higher level of tolerance and acceptance towards these elements. As a result, manga that is considered taboo and banned in the United States and Hong Kong is received well in the Japanese market. Based on the images of body parts, lingerie and naked bodies that were being censored in the Malay translations identified in this study, researchers concluded that the acceptance of nudity in Malaysia is relatively conservative compared to the acceptance by Japanese readers.

It is significant to note that different procedures were adopted to reduce sensitivity conveyed by body parts and to ensure the aesthetic values of images are retained, even in translations published by the same publisher. Yet, some of these sensitive images are repeated in a few target texts. The repetitions of sensitive body parts are believed to be unintentional and are left out, as these images are regarded as sensitive in the publishing guideline and the number of occurrences is little.

\section{Kissing}

A kissing scene is found in 式の前日 $(2012,62)$. In the target text, the characters' mouths are erased. This modification is in line with the publishing guideline, which stated that images of couples kissing are not allowed in any publications.

\section{Abusive, vulgar and obscene language}

The publishing guideline states that the use of obscene, abusive and vulgar languages, and language which gives the same meaning as such, including humorous jokes, are not allowed in any publications. Analysis of sensitive written representations indicates that the category "abusive, vulgar and obscene language" score the highest number of occurrences. Findings show that all publishers choose to censor vulgar languages by adopting the procedures of substitution (with nonvulgar languages) and deletion. 
Substitution is used to replace vulgar languages with non-vulgar or less vulgar language. For example, in a panel in the manga 君の名は $01(2016 b, 51)$, the heroine's younger sister says the following “あほやなあ”( a ho ya naa), which literally means "what a fool", to tease her elder sister. As she thinks her elder sister performed a silly act of shouting loudly to ask God to change her gender, “あほやなあ” is translated with a less vulgar equivalent "lembap betul”, which literally means "totally silly/stupid/slow". This translation sounds less abusive in Malay.

In addition, deletion is also used by all publishers to handle vulgar language. For example, in the manga One Piece 80 (2015, 156), a character uses “おのれ” (onore), which means "You bastard!" warning a few characters not to enter a country without permission. おのれ (onore) is deleted from the target text and this translation was produced: "Tapi... Tak boleh masuk negara asing tanpa kebenaran..." (But... [you guys] cannot enter a foreign country without permission...). Another vulgar word that is often used in manga to express anger or annoyance is バカ $(b a k a)$. This vulgar word is translated via the substitution or deletion procedure.

\section{Translation procedures used in self-censorship}

Table 3 represents types of self-censored representations and the translation procedures used in handling self-censorship of the image and written messages that are considered as inappropriate content by the publishers. The self-censored written representations are names of alcoholic beverages, words related to religion and cigarettes. In addition, images of cigarettes and cigars were self-censored in the target texts.

\section{Names of alcoholic beverages}

Based on the explanation under the subtitle of "advertisement" in the publishing guideline, advertising alcoholic beverages is not allowed in Malay language publications. Though it is allowed in publications of other languages, it must not portray on the front or back covers. The stated reason is that advertisements of alcoholic drinks can trigger social sensitivity among certain Malaysians. Based on these statements, images or written messages of alcoholic drinks, but ones that do not act as advertisements in manga, can be regarded as non-sensitive. Despite that, some publishers impose censorship to written names of alcohol beverages. 
Table 3. Translation procedures used in censoring image and written representations which are not stated in the guideline: Number of occurrences

\begin{tabular}{llc}
\hline Written representations & Translation procedures & Number of occurrences \\
\hline Names of alcoholic beverages & Substitution & 22 \\
& Deletion & 4 \\
& Repetition & 4 \\
\hline Words related to religion & Substitution & 20 \\
& Repetition and addition & 5 \\
& Repetition & 3 \\
\hline Cigarettes & Substitution & 1 \\
\hline & Total & 59 \\
\hline Image representations & Translation procedures & Number of occurrences \\
\hline Cigarettes and cigars & Deletion & 3 \\
& Addition & 4 \\
& Repetition & 60 \\
\hline
\end{tabular}

The analysis reveals that alcohol names are found to appear outside and inside the speech bubbles. Substitution is the most frequently used procedure to deal with alcoholic drinks' written depictions inside speech bubbles. It is performed by substituting the alcoholic drinks with a food name or a hypernym. In a panel in 式の前日 $(2012,57)$, a male character is asking his brother “最初生でいいか” (saisho nama de $\bar{\imath} \mathrm{ka}$, “Is it fine to order two beers first?”). After the brother expressed his agreement “ああ” (ā, "Yes”), the male character says “生二つ” (nama futatsu, “Two beers, please") to the waitress. 生 (nama) is the abbreviation for 生ビール (nama biru), which refers to a type of beer that is processed with a micro filter technique for the purposes of sterilisation. As it is not sterilised by using heat, it is known as 生 (nama), which literally means "raw".

In the Malay translation, the first speech balloon “最初生でいいか” is translated as "Ada sashimi tak?" (Do you have sashimi?). This translation shows that the translator substituted 生 (nama) with "sashimi", which refers to the bite-sized pieces of raw fish eaten with soy sauce and wasabi paste. Whereas in the second speech balloon, “ああ”, which was supposed to be spoken by the brother, is translated as ada (have) as spoken by the waitress. If the translator purposely modified the speaker of the second speech balloon from "spoken by his brother" to "spoken by the waitress", the translations would have reflected that the translator 
is trying to avoid mentioning alcoholic drinks by substituting it with the name of a food, subsequently modifying the original message. Conversely, if this is not the case, the translator interpreted the message in this particular panel wrongly.

Substitution with hypernyms is also used to deal with names of alcoholic drinks. For instance, in a panel of 式の前日 $(2012,58)$, the male character is telling his brother that he visits the restaurant regularly and explains further that the restaurant offers a variety of alcoholic beverages and the food is tasty too. The dialogue “酒の種類も豊富だし” (sake no shurui mo höfudashi, “There are various kinds of alcoholic beverages") in the first panel interacts complementarily with the image (images of Japanese sake bottles) in the second panel, to inform that the restaurant offers various kinds of alcoholic beverages. In the Malay translation, the kanji 酒 (sake) is substituted by a hypernym minuman (drinks). By doing this, only readers familiar with Japanese sake bottles will be able to interpret that the drinks referred to in the target text are actually the alcoholic beverages.

Conversely, deletion is used to remove words on images. For example, in 式の前日 $(2012,74)$, a few close-ups of a page are used to show a male character feeling dejected and despondent. The last panel of the page is a close-up of the image of a canned drink. The word "BEER" is clearly printed on the can. These panels show that the character is feeling sad and is drinking alcohol. The publisher adopted deletion to erase the word "BEER" from the target text. This modification portrays a character drinking something. With this, the act of "alleviating sorrow by drinking beer" is not conveyed in the target text as clearly as it is in the source text.

Also, deletion is adopted to censor alcohol names inside the speech bubbles. Three kanji 酒 (sake), which refer to alcohol in 名探偵コナン 81 (2013, 40;46; 56), are found deleted from the target text. For example, a panel is present showing Kogoro Mouri, who is drinking a glass of Gimlet in a pub, and Conan, who came to ask him to return home was standing behind him. Kogoro Mouri tells Conan, “仕事中だって言ってんだろ一が!” (shigoto chū datte itten darō ga, “I have told you I am working!"). Another thought bubble is present indicating Conan's monologue “酒、飲んでるだけじゃね一か!” (sake, non deru dake ja nē ka, "You are just drinking alcohol!"). Conan is blaming Kogoro Mouri. In the Malay translation, Conan's monologue is translated as "Aku nampak kau sedang minum!" (I see you are drinking!). The target text only mentioned that the character is drinking by using the verb minum, but the type of drink is not mentioned. Nevertheless, readers can still guess that Kogoro Mouri is drinking an alcoholic drink from the image of the cocktail glass. Also, the translation is congruent with the visual. 
This discussion shows that even though names of alcohol in manga can be regarded as non-sensitive, most of the names are substituted and deleted. This shows that the expected target audience of translated manga in Malaysia is perhaps children and teenagers, who are perceived as vulnerable.

Nevertheless, findings also show that some alcoholic drinks names are repeated in the translation. For example, in 名探偵コナン 81 (2013, 46), Kogoro Mouri is requesting a cocktail named "gimlet" (ギムレット, gimuretto) from the female bartender. The cocktail's Japanese name ギムレット (gimuretto) is borrowed from the English name "gimlet", it is a cocktail made from gin or vodka and lime juice. The original English name of the alcoholic drinks is repeated as "gimlet" into the target text "Tolong beri satu gimlet lagi!" (Please give me another gimlet!). Another example of repetition is the Japanese sake named 口噛み酒 (kuchikami zake), which is depicted as 日本最古の打酒 (nihon saiko no o sake, the Japan's oldest liquor) in the manga 君の名は 01 (2016b, 45). It had been transliterated as Kuchikamizake in the Malay translation.

The repetitions of alcohol names in some of the translations imply that an inconsistency exists in handling alcohol names in manga. This may be due to the fact that different translators exhibit different interpretations towards the publishing guideline, and this leads to different selections of translation procedures. Also, this shows that the publishers are not sharing the same agency, even in manga published by the same company. For instance, Kadokawa Gempak Starz Sdn. Bhd. adopted different translation procedures to omit as well as retain the names of alcoholic beverages. If the act of drinking an alcoholic drink is depicted as a traditional custom that conveys positive value, the name of the alcohol is retained. In brief, names of alcoholic beverages were censored in the translations published by Art Square Creation Sdn. Bhd. and Kadokawa Gempak Starz Sdn. Bhd. In contrast, the names of alcoholic beverages were not censored by Penerbit Tora Aman, Comics House Sdn. Bhd. and Kadokawa Gempak Starz Sdn. Bhd.

\section{Words related to religion}

As stated in the publishing guideline, special Islamic terms such as Allah, Baitullah (the House of Allah), solat (the prayer) and Kaabah (the Kaaba) are not allowed to be used in the publication of religion other than Islam. This means that religious words other than these specific terms could be published in non-Islamic texts, including manga. However, findings show that religious words are handled with the substitution and couplet procedures "repetition and addition". Substitution is the most frequent used procedure. The substitution of 神様 (kamisama, God) with dewa (deity) is performed by all publishers. This is perhaps to avoid 
contradiction to the belief in one God in Islam. In addition, words related to the Shinto religion are found replaced by a general word, for example 神事 (shin ji), which refers to the Shinto rituals is substituted by the word upacara (ceremony), instead of upacara Shinto.

However, not all religious words are substituted with more general words. In manga 君の名は 01 (2016b, 144), the transliteration of some religious terms is retained in the target text (repetition). For instance, カクリヨ (kakuriyo), which refers to the realm of the dead or afterlife, is translated as Kakuriyo. The meaning of this term is explained in the next bubble by the same speaker as “あの世のことやわ” (anoyo no koto ya wa, "It is the other world”). Thus, the repetition does not pose any difficulties in understanding for readers. In addition, some Shinto religion related words are repeated in the target text in its transliteration form with additional explanation. For instance, ご神体 (goshintai), the sacred object or the object of worship at the Shinto Shrine, is repeated in the Malay translation as Goshintai, and an additional explanation objek pemujaan tempat roh atau dewa menghuni (the object of worship where the spirit or God dwells) is added to explain the Japanese transliteration.

The use of repetition and addition in translating the Shinto religion related words show that Malaysian publishers intend to introduce foreign culture to Malaysian readers. The comparison between the application of "substitution" and the couplet procedures "repetition and addition" show that only the direct reference to Tuhan (God) is substituted with another word. Thus, Tuhan is regarded as a special Islamic term among publishers, although this term is not listed in the guideline as a specific Islamic term. As such, this censorship can be regarded as self-censorship.

\section{Cigarettes and cigars}

The publishing guideline indicates that advertisements of tobacco or any products using the brands of tobacco products, as well as any articles that promote tobacco or its uniqueness are prohibited. However, pictures of people smoking are allowed if the brand of the cigarette is not displayed (Bahagian Kawalan Penerbitan dan Teks Al-Quran 2017). This statement proved that images depicting smoking are not regarded as prohibited images in manga, as the above-mentioned regulations are only applied to advertisements. Yet, analysis found two procedures used by two publishers to censor images of cigarettes or cigars. Deletion is used by Art Square Creation Sdn. Bhd. to erase the illustrations of cigarettes in Raikan Cinta $(2016,62)$. Conversely, Penerbit Tora Aman adopts addition by using pixelate to cover the image of the cigarette. However, the pixelate was not applied to cover 
wisps of smoke coming from the cigarette. This has caused an incongruent image of an absent cigarette with the image of smoke rising from nowhere in the target text.

In a panel of 式の前日 $(2012,25)$, the seven-year-old character Azusa is blaming her father for never returning home after telling her that he went to buy cigarette, “だっておとうさん「タバコ買ってくる」って言ってそのままも う家帰ってこなかったし”(datte otōsan “tabako katte kuru” tte itte sonomama $m \bar{o}$ ie kaette konakattashi, "This is because you said "I want to go to [the shop] to buy cigarette' but you didn't return home anymore"). In the target text, "Sebab dulu ayah cakap, 'Nak pergi kedai beli barang sekejap!' Tapi lepas tu ayah tak balik-balik" (As last time you said, "I want to go to the shop to buy something!" But after that, you never come back). The Malay translation shows that the translator substituted "cigarette" with barang (something).

These findings show that Art Square Creation Sdn. Bhd. and Penerbit Tora Aman are found sharing the same agency, in which the images of cigarettes were erased or covered, and the word "cigarette" was substituted in their publications. Both publishers see depictions of smoking as representations that needed to be censored. Conversely, Comics House Sdn. Bhd. did not censor the images of cigarettes and cigars. This finding is in line with the statement about censorship of cigarettes and cigars in the guideline. Thus, censoring depictions of smoking can be considered as self-censorship.

\section{Conclusion}

This article aims to identify the translation procedures used in institutional censorship and self-censorship as well as to suggest translation procedures that can be adopted as guidelines in manga translation in Malaysia. The study found that the censored images and written representations in the corpus constitute sensitive body parts including lingerie, the act of kissing, cigarettes and cigars, abusive, vulgar and obscene language, names of alcoholic beverages, and words related to religion.

A few translation procedures were adopted for institutional censorship, which consist of detraction, addition, substitution, deletion and the couplet procedure of "detraction and addition". These procedures can become guidelines to assist translators, publishers, and the Ministry of Home Affairs to perform institutional censorship. Conversely, self-censorship is performed using substitution, deletion and addition. However, some similar elements which are censored in both types 
of censorship are also retained in the translations using "repetition" and the couplet procedure of "repetition and addition". Among the identified procedures, the detraction, addition, substitution, and couplet procedures are performed with creative modification techniques, to ensure that the complimentary relationship of written and image representations are well transformed into the target texts.

Based on the agency of Malaysian translators and publishers in dealing with the sensitive image and written representations, we can deduce that the social characteristics of Malaysia, influences the censorship practices in manga translation in Malaysia. In terms of the acceptance of nudity and vulgar languages, Malaysia's social acceptability is relatively conservative. Thus, censoring these elements is one preventive measure established in Malaysian rules and regulations. Besides, the identified censorship norms clearly reflect that the source texts are targeted to adult readers, while the target texts are targeted to the public at large, which are mainly children and teenagers. This deduction can be supported by the self-censorship of names of alcoholic beverages and cigarettes performed by some publishers. The self-censorship is driven by their individual awareness on social responsibility and the vulnerability of the target readership. Moreover, the identified censorship norms can also be related to religious reasons. Malaysia's official religion is Islam, and smoking and drinking alcohol are prohibited in Islam as they are harmful to the human body. Usage of vulgar languages and profanity are also considered as unbecoming and should be avoided in the Malaysian culture. In other words, social acceptability, target readership, religion and socio-cultural differences between Japan and Malaysia are factors underpinning the censorship norms in manga translation in Malaysia.

The context of use for translated manga changed from the Japanese social context to the Malaysian social context. This change has prompted Malaysian publishers to reshape the image and written messages that are discouraged in Malaysia's socio-cultural context by using various translation procedures. The publishing guideline serves as the ethical principle for publication. However, it is also crucial to point out the fact that the publishers also perform self-censorship in response to the assumptions of social acceptability in the face of Malaysia's socio-cultural context that they themselves had created. Therefore, censorship in manga translation in Malaysia can be regarded as a result of a combination of institutional and individual censorship. This finding shows that manga translation imposed self-censorship that is not listed in the guideline. Thus, a revision of the publishing guideline or screening process should be conducted by the Ministry of Home Affairs so that censorship imposed on the translated manga is in line with the publishing guideline. With this, readers are believed to be able to enjoy a more faithful message representation as it exists in the source text. There are also other 
censorship norms that can be explored with a bigger corpora in future studies and the findings can perhaps be complemented with justifications obtained through interviews with the translators, publishers or ministry so as to shed some light on the reasons for performing self-censorship.

\section{Acknowledgements}

This research was supported by the Universiti Sains Malaysia Short-Term Grant (304/PHUMANITI/6315471).

\section{Corpus}

Aoyama, G. 2017. Detektif Conan 83. Selangor, Malaysia: Penerbit Tora Aman. 2016. Detektif Conan 81. Selangor, Malaysia: Penerbit Tora Aman. 2014. 名探偵コナン 83. Tokyo: Shogakukan Inc. 2013. 名探偵コナン 81. Tokyo: Shogakukan Inc.

Hozumi. 2016. Raikan cinta, translated by R. Saffie. Kuala Lumpur: Art Square Creation Sdn. Bhd. 2012. 式の前日. Tokyo: Shogakukan Inc.

Oda, E. 2016a. Budak Getah 80: Perisytiharan permulaan baru (kaimaku sengen). Selangor, Malaysia: Comics House Sdn. Bhd. 2016b. Budak Getah 81: Pergi berjumpa dengan Tuan (master) Nekomamushi. Selangor, Malaysia: Comics House Sdn. Bhd. 2016c. One Piece 81 ネコマムシの旦那に会いに行こう. Tokyo: Shueisha Inc.

2015. One Piece 80 開幕宣言. Tokyo: Shueisha Inc.

Shinkai, M. and Kotone, R. 2016a. NAMAMU...01, trans. Uepinmon. Kuala Lumpur: Kadokawa Gempak Starz Sdn. Bhd. . 2016b. 君の名は 01. Tokyo: Kadokawa Corporation.

\section{References}

Badrul Redzuan Abu Hassan. 2015. Prospek penapisan kendiri: Analisis wacana sinema serantau. GEOGRAFIA Online: Malaysia Journal of Society and Space 11(2): 1729.

Bahagian Kawalan Penerbitan dan Teks Al-Quran. 2017. Garis panduan penerbitan di bawah Akta Mesin Cetak dan Penerbitan 1984 [Akta 301]. Putrajaya: Kementerian Dalam Negeri.

Barrale, N. 2018. Foreign literature as poison: (Self-)censorship in the translation of German popular fiction in Italy during the 1930s. Perspectives 26(6): 852-867. https://doi.org/10.1080/0907676X.2018.1444070

Billiani, F. 2009. Censorship. In Routledge encyclopedia of translation studies, eds. M. Baker and G. Saldanha, 28-30. New York: Routledge. 
Borodo, M. 2015. Multimodality, translation and comics. Perspectives 23(1): 22-41. https://doi.org/10.1080/0907676X.2013.876057

Hanim Hafiza Mohd Hanif. 2014. Satu analisis terjemahan humor dalam buku komik Crayon Shin Chan. Master's diss., Universiti Sains Malaysia.

Hsieh, H.F. and Shannon, S.E. 2005. Three approaches to qualitative content analysis. Qualitative Health Research 15(9): 1277-1288. https://doi.org/10 $.1177 / 1049732305276687$

Huang, C.W. and Archer, A. 2014. Fluidity of modes in the translation of manga: The case of Kishimoto's Naruto. Visual Communication 13(4): 471-486. https://doi.org/10.1177/1470357214541746

Japan Book Publishers Association. 2017. An introduction to publishing in Japan 20172018. Tokyo: Japan Book Publishers Association.

Jüngst, H.E. 2004. Japanese comics in Germany. Perspectives 12(2): 83-105. https://doi.org/10.1080/0907676X.2004.9961493

Kadokawa Corporation. 2015. マレシアArt Square Group の株式取得および同国政 府機関InvestKLによる事業支援に関するお知らせ。 Retrieved from https://ir .kadokawa.co.jp/topics/20151105_t4shx.pdf (accessed 1 January 2020).

Kaindl, K. 1999. Thump, Whizz, Poom: A framework for the study of comics under translation. Target: International Journal of Translation Studies 11(2): 263-288.

Natsume，F. 1997. マンガはなぜ面白いのかーその表現と文法. Tokyo： NHK Publishing, Inc.

O’Hagan, M. 2007. Manga, anime and video games: Globalizing Japanese cultural production. Perspectives 14(4): 242-247. https://doi.org/10.1080/090767607 08669041

Rampant, J. 2010. The manga polysystem: What fans want, fans get. In Manga: An anthology of global and cultural perspectives, ed. T. Johnson-Woods, 221-232. New York/London: Continuum International Publishing Group.

Roslina Mamat, Hazlina Abdul Halim, Shahila Mansor and Roswati Abdul Rashid. 2018. Penggunaan manga dan anime sebagai media pembelajaran dalam kalangan pelajar bahasa Jepun di universiti awam Malaysia. Malaysian Journal of Communication 34(3): 298-313.

Rota, V. 2008/2014. Aspects of adaptation. The translation of comics formats. In Comics in translation, ed. F. Zanettin, 129-157. Manchester/Kinderhook: St. Jerome Publishing.

Saldanha, G. and O'Brien, S. 2014. Research methodologies in translation studies. London/New York: Routledge.

Takeyama, Y. and Armour, W.S. 2015. Translating Japanese typefaces in "Manga": Bleach. New Readings 15: 21-45.

Ye， H. 2010. マレシーアにおける日本文化一日本語教育から文化翻訳まで. Ritsumeikan Studies in Language and Culture 21(3): 83-93.

Zanettin, F. 2018. Translation, censorship and the development of European comics cultures. Perspectives 26(6): 868-884. https://doi.org/10.1080/0907676X.2017.1351456

2014. Visual adaptation in translated comic. inTRAlinea: Online Translation Journal 16. Retrieved from http://www.intralinea.org/archive/article/visual_ adaptation_in_translated_comics (accessed 1 January 2020). 
2008/2014a. Comics in translation: An overview. In Comics in translation, ed. F. Zanettin, 16-62. Manchester/Kinderhook: St. Jerome Publishing.

2008/2014b. The translation of comics as localization. On three Italian translations of La piste des Navajos. In Comics in translation, ed. F. Zanettin, 316344. Manchester/Kinderhook: St. Jerome Publishing.

Zitawi, J. 2008/2014. Disney comics in the Arab culture(s). A pragmatic perspective. In Comics in translation, ed. F. Zanettin, 152-171. Manchester/Kinderhook: St. Jerome Publishing. 